\title{
TeACHing For The Tithe: Donor EXPECTATIONS AND The Matrona's Tithe Krista Dalton
}

\begin{abstract}
This article examines a story in the Jerusalem Talmud depicting a wealthy woman who expects Torah instruction in exchange for her tithes. This textual example is used as a lens through which to view the changing social, religious, and economic relationships of Roman Syria Palaestina, whereby the biblically described institution of tithing to priests expanded to include priestly descendent rabbis. Giving the priestly tithe to a rabbi, while advantageous in a period of rabbinic fundraising, presented a distinct set of challenges as it came to resemble patronage practices associated with Roman elites. Through close textual analysis of the wealthy woman's tithe, the prominence and consequences of scholastic donations are examined, both in rabbinic literature and in the broader late ancient Mediterranean. ${ }^{1}$
\end{abstract}

Scholastic expertise in the ancient world depended on donor networks. ${ }^{2}$ These relationships brought not only gifts, favors, and social capital to scholarly guilds, but also cultivated the legitimacy of scholarly authority. Expertise was not self-evident; it had to be performed and required validation from others. Yet, while useful, these donor relationships introduced specific tensions. Once gifts and favors were exchanged, donors could feel entitled to the scholastic work and thereby threaten scholarly autonomy. ${ }^{3}$ Scholarly autonomy went hand in hand with claims to exclusive knowledge. Scholars negotiated this tension by asserting their expert authority over donors through rhetorical tactics that masked the power of donor support. ${ }^{4}$

1. I want to thank Beth Berkowitz, Alyssa Gray, Sarit Kattan Gribetz, Simcha Gross, David Maldonado Rivera, and the anonymous reviewers for their helpful comments and suggestions on various iterations of this idea.

2. On the application of social network theory to the ancient Roman world, see Anna Collar, Religious Networks in the Roman Empire: The Spread of New Ideas (New York: Cambridge University Press, 2013).

3. The reciprocal expectations of gift exchange have been widely documented, most notably by Marcel Mauss, The Gift: The Form and Reason for Exchange in Archaic Societies (London: Routledge, 2002). For commentaries on Mauss's work, see Claude Lévi-Strauss, Introduction to the Work of Marcel Mauss (London: Routledge \& Kegan Paul, 1987); Marshall David Sahlins, Stone Age Economics (London: Routledge, 2004), 149-83; Raymond Firth, Symbols: Public and Private (Ithaca, NY: Cornell University Press, 1975), 368-402; Jonathan Parry, "The Gift, the Indian Gift and the 'Indian Gift," Man 21, no. 3 (1986): 453-73; Pierre Bourdieu, The Logic of Practice (Stanford, CA: Stanford University Press, 1990), 98-111; Annette B. Weiner, Inalienable Possessions: The Paradox of Keeping-While-Giving (Berkeley: University of California Press, 1992); James G. Carrier, Gifts and Commodities: Exchange and Western Capitalism since 1700 (London: Routledge, 1995).

4. See, for example, Kendra Eshleman's The Social World of Intellectuals in the Roman Empire: Sophists, Philosophers, and Christians (Cambridge: Cambridge University Press, 2012). 
The rabbis of Syria Palaestina participated in these habits of the ancient Mediterranean knowledge marketplace. While some rabbinic texts are explicitly wary of the Roman patronal system, ${ }^{5}$ other accounts attest to expanding rabbinic social networks and relationships with donors. ${ }^{6}$ This expansion came with its own particular tensions. In addition to the unsavory expectations of reciprocal exchange and encroachment on rabbinic autonomy, rabbinic ideals derived from the Torah itself resisted relationships of debt. Identifying donor relationships in rabbinic literature is thereby complicated by the fact that the rabbis themselves often thwarted associations with systems of patronage. While textually veiled, some rabbinic texts retain glimpses of rabbinic donor relationships that help us theorize what such relationships might have looked like in practice within an ancient Mediterranean context.

Using an anecdotal story depicting an encounter between a rabbi and a wealthy woman (matrona), this article demonstrates some of the anxieties attendant to rabbinic donor relationships, particularly with women. In this passage from the Jerusalem Talmud, a rabbi dismisses a wealthy woman's question concerning a biblical story with vitriolic insistence that as a woman she is categorically unfit to be taught Torah at all. Here I will expose the positionalities informing the encounter, expanding upon the gendered dynamics of the text, as most scholarship has emphasized, ${ }^{7}$ but also adding the dimension of donor expectations. $^{8}$

5. See Seth Schwartz, Were the Jews a Mediterranean Society? Reciprocity and Solidarity in Ancient Judaism (Princeton, NJ: Princeton University Press, 2009).

6. Hayim Lapin in Economy, Geography, and Provincial History in Later Roman Palestine (Tübingen: Mohr Siebeck, 2001), 182, argues that the "network of patronage ties centered on city elites and extend[ed] outward into the village." See also Hayim Lapin, "Jewish and Christian Academies in Roman Palestine: Some Preliminary Observations," in Caesarea Maritima: A Retrospective after Two Millennia, ed. Avner Raban and Kenneth Holum (Leiden: Brill, 1996), 496-511. For analysis of rabbinic donor relationships in the cultivation of expertise, see Krista Dalton, "Rabbis and Donors: The Logics of Giving in the Ancient Mediterranean" (PhD diss., Columbia University, 2019). For the particular case of Rabbi Akiva's wife as a donor, see Susan Marks, "Follow That Crown: Or, Rhetoric, Rabbis, and Women Patrons," Journal of Feminist Studies in Religion 24, no. 2 (2008): 77.

7. See the following studies on the matrona's gender and rabbinic Torah study: Jenny Labendz, Socratic Torah: Non-Jews in Rabbinic Intellectual Culture (Oxford: Oxford University Press, 2013), 108; Tal Ilan, Jewish Women in Greco-Roman Palestine: An Inquiry into Image and Status (Tübingen: Mohr Siebeck, 2006), 191; and Michael Satlow, “'Try to Be a Man': The Rabbinic Construction of Masculinity," Harvard Theological Review 89, no. 1 (1996): 35.

8 . Here I draw on the theoretical apparatus of intersectionality, which contends that social categorizations, such as gender, race, and class, are interconnected and create overlapping experiences of marginalization. See Kimberlé Crenshaw, "Demarginalizing the Intersection of Race and Sex: A Black Feminist Critique of Antidiscrimination Doctrine, Feminist Theory and Antiracist Politics," University of Chicago Legal Forum (1989): 139-68; Crenshaw, "Intersectionality and Identity Politics: Learning from Violence against Women of Color," in Reconstructing Political Theory: Feminist Perspectives, ed. Mary Lyndon Shanley and Uma Narayan (University Park: Pennsylvania State University Press, 1997), 178-93; Devon W. Carbado, Kimberlé Williams Crenshaw, Vickie M. Mays, and Barbara 
My argument is two-fold. First, I focus on an oft-neglected detail of the passage, in which the wealthy woman proceeds to withdraw her yearly tithe in response to the rabbi's dismissal. I contend that this wealthy woman's tithe operated as a reciprocally informed donation, which runs contrary to the Hebrew Bible's legislation concerning priestly tithes. Tithes were not intended to create networks of social dependency, as patronage relationships encouraged. ${ }^{9}$ When the wealthy woman sought to benefit from rabbinic expertise in exchange for her gift, her tithe was functioning as a donation with reciprocal expectations. Identifying the tithe as a reciprocal donation provides an opportunity to compare the matrona's tithe to other examples of rabbinic donations.

Second, I argue that recognizing the wealthy woman as a rabbinic donor resists reducing her role in the text solely to her womanhood. ${ }^{10}$ Instead, I argue that gender is operative and can be employed in a dynamic and negotiable process, informed by more than one concern or distinction. As Joan Scott writes concerning the purpose of gender analysis, "The new historical investigation is to disrupt the notion of fixity, to discover the nature of the debate or repression that leads to the appearance of timeless permanence in binary gender representation. ${ }^{" 11}$ By interrogating the matrona's role in the text beyond just her gender, the interrelated dynamics of class and social logic at work in this text allow us to think about habits of and tensions surrounding scholastic giving more broadly, and the way that gender was imbricated alongside a host of other concerns.

\section{The Matrona And Her Tithe in Context}

The Jerusalem Talmud, whose major redaction is typically dated to the beginning of the fifth century $\mathrm{CE},{ }^{12}$ contains a heated exchange in tractate Sotah between a wealthy woman, called a matrona,${ }^{13}$ and Rabbi Eliezer:

Tomlinson, "Intersectionality: Mapping the Movements of a Theory," Du Bois Review: Social Science Research on Race 10, no. 2 (2013): 303-12.

9. Marina Rustow contends that this obligation created a gift-giving system between God and the Israelites that formed a network of solidarity. She explains, "They [the Levites] had to receive gifts from the landed Israelite tribes, who could not volunteer those gifts as individuals or to individuals, since doing so would have entangled them in relationships of dependence." "Patronage in the Context of Solidarity and Reciprocity: Two Paradigms of Social Cohesion in the Premodern Mediterranean," in Patronage, Production, and Transmission of Texts in Medieval and Early Modern Jewish Cultures, ed. Esperanza Alfonso and Jonathan P. Decter (Turnhout: Brepols, 2014), 21.

10. Joan Scott criticizes such a reductive reading of the historical record in "Gender: A Useful Category of Historical Analysis," The American Historical Review 91, no. 5 (1986): 1053-75. Such readings reify a reductive opposition between men and women and make gender an essential fact.

11. Ibid., 1068.

12. H. L. Strack and Günter Stemberger, Introduction to the Talmud and Midrash (Minneapolis, MN: Fortress Press, 1996), 171.

13. The text does not specify whether the matrona is a Jew or a gentile, nor does it specify her marital status (is she a widow?) or specific class (what was her husband's means of income and social status?). The reference to a matrona appears in a few other places in Palestinian rabbinic literature, though it is unclear if these stories should be understood as referring to the same matrona or to nameless 


\section{Krista Dalton}

A matrona asked R. Eliezer: "How is it that, though only one sin was committed during the golden calf event, those who died, died by three kinds of punishments?" He said to her, "Woman has no wisdom except at the spindle, for it is written, "And all the women that were wise-hearted spun with their hands"" [Exodus 35:25]. Hyrcanus, his son, said to him: "So as not to answer her with a single teaching from the Torah, you made me lose three hundred kors of tithe per year!" He said to him, "May they burn the words of Torah rather than deliver them to women." (Y. Sotah 3:4 [19a])

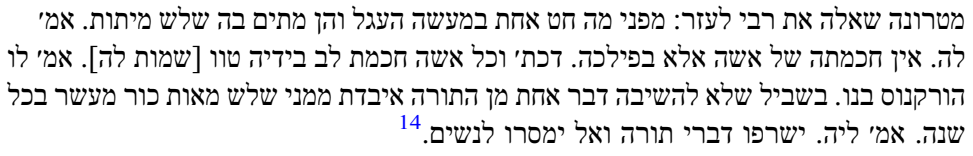

The passage begins with the matrona asking why the Israelites' construction of a golden calf led to three different punishments. ${ }^{15}$ Her question incisively probes the narrative multiplicity in the Exodus account, which describes the Israelite

matronas who happen to exchange words with famous rabbis. Because of the Latin resonances of the title matrona, scholars have long assumed that the matrona represented a wealthy non-Jewish matron. For example, Michael Satlow suggests that the matrona embodies "double alterity, she is both a non-Jew and a woman." Satlow, "Fictional Women: A Study in Stereotypes," in The Talmud Yerushalmi and Graeco-Roman Culture, ed. Peter Schäfer (Tübingen: Mohr Siebeck, 2002), 3:239. Tal Ilan, by comparison, insists that the matrona might represent a Jewish woman or could be the personal name of a Jewish woman. Tal Ilan, "Matrona and Rabbi Jose: An Alternative Interpretation," Journal of Jewish Studies 25 (1994): 49, and Ilan, Jewish Women in Greco-Roman Palestine, 200-204. Given this matrona's habit of tithing, it may be most natural to assume she is a wealthy Jewish woman, though such assumptions do not allow for the possibility that gentiles who adopted ancient Jewish piety practices might give money to rabbis using the language of tithes. See for example Shelly Matthews, First Converts: Rich Pagan Women and the Rhetoric of Mission in Early Judaism and Christianity (Palo Alto, CA: Stanford University Press, 2001), 63-64. Nor is it so clear that the matrona is not Jewish because of the use of a Roman title. Immediately following this passage, R. Eliezer's students use the trope "this one you pushed away with a stick," which often occurs when a gentile asks a rabbi a question. I propose it is best to leave the matrona's ethnoreligious identity open and entertain the possibilities of both a Jewish and gentile donor.

14. I rely on the Leiden manuscript, as published in Y. Sussmann, Talmud Yerushalmi (Jerusalem: Academy of the Hebrew Language, 2016), column 920. There is a slight variant in the Vatican Manuscript Ebreo 133, and in the reconstruction from the Geniza fragments published by Louis Ginzberg, Yerushalmi Fragments from the Genizah (New York: The Jewish Theological Seminary of America, 1909), 209, which render ממנו as. This variant does not affect the sense of the story. There is also a problem with identifying the correct רבי לעזר. While "Lazar" usually refers to R. Eleazar, here לעזר is better vocalized "Liezer," referring to R. Eliezer, since his son Hyrcanus is also mentioned. Lazar may be a scribal error, especially since the prior sugya features a teaching of R. Eleazar. See also Bamidbar Rabbah 9. A related parallel appears in Bavli Yoma 66b, which will be discussed later in this article.

15. On the reception of the golden calf episode in rabbinic and patristic literature, see Leivy Smolar and Moshe Aberbach, "The Golden Calf Episode in Postbiblical Literature," Hebrew Union College Annual 39 (1968): 91-116. 
construction of an idol when Moses failed to return speedily from Mount Sinai. In the biblical text, the Israelites died from three different punishments for the singular sin of constructing a golden calf: the Levites killed 3,000 men (Exodus 32:28), some people died of a plague (Exodus 32:35), and Moses ground the golden calf to dust and spread it over the water supply, forcing the people to drink in imitation of the sotah ritual (Exodus 32:20). ${ }^{16}$ Her question not only attends to the intricacies of the biblical narrative, but also reflects the rabbinic hermeneutical assumption of measure-for-measure punishments. ${ }^{17}$ The matrona therefore asks a trenchant exegetical question of the Torah, animated by rabbinic hermeneutical concerns.

Before attending to the matrona's encounter with R. Eliezer, we must first recognize the significance of such an exchange occurring textually in a tractate devoted to the sotah ritual. The sotah ritual derives from Numbers 5:11-31, which describes the proper process for jealous husbands who wish to investigate wives they suspect of adultery. The husband is instructed to bring his wife before a priest to consume a prepared potion of "holy water" mixed with dust from the tabernacle floor. The priest writes the words of the sotah curse on parchment and stirs the ink into the water before prompting the woman to drink of the mixture. After the woman drinks, the potion manifests the bodily evidence of her guilt, her "belly

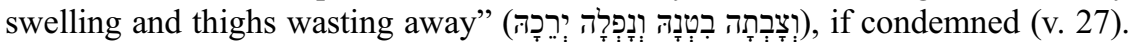

That the rabbis devoted an entire tractate to this biblical ritual, which could no longer be observed following the destruction of the Temple in $70 \mathrm{CE}$, is striking. Not only do they attend to the laws within the biblical text, they expand and reframe them. In what Ishay Rosen-Zvi describes as a "fantasy of control," the rabbis used the ritual as a means for thinking about the nature of women broadly so as to transform the "sinful, proactive and dangerous wife into a passive, submissive and unthreatening subject." for analyzing the "threats inherent to womankind," which the rabbis could control and neutralize in their conceptions of how women ought to behave. ${ }^{19}$

Such thematic extrapolation from the individual sotah to women writ large is illustrated in the mishnah to which our talmudic passage responds. The severity of the signs of a sotah's guilt provoked a mishnaic discussion about possible mitigation of the ritual's curse. ${ }^{20}$ This mishnah interjects that a woman might stave off

16. The grinding of the golden calf in imitation of sotah is also discussed in B. Avodah Zarah $44 \mathrm{a}$ in the context of turning idols to dust. See 2 Chronicles 25:16 and 2 Kings 18:4 for other occasions of idol destruction.

17. Ishay Rosen-Zvi argues that the rabbis employ this principle as a hermeneutical tool especially in discussions about the sotah ritual. "Measure for Measure as a Hermeneutical Tool in Early Rabbinic Literature: The Case of Tosefta Sotah," Journal of Jewish Studies 57, no. 2 (2006): 269; Rosen-Zvi, The Mishnaic Sotah Ritual: Temple, Gender and Midrash (Leiden: Brill, 2012).

18. Rosen-Zvi, Mishnaic Sotah Ritual, 229.

19. Ibid., 225.

20. Michael Satlow argues that rabbinic literature goes beyond the biblical ritual and exaggerates the humiliation of the woman's experience. Michael Satlow, “Texts of Terror': Rabbinic Texts, Speech Acts, and the Control of Mores," AJS Review 21, no. 2 (1996): 276. 


\section{Krista Dalton}

the curse through the accumulation of merit (for one, two, or three years) ${ }^{21}$ While the means of accumulating merit is initially unspecified, the resulting debate assesses whether Torah learning is a possible tactic:

On this basis Ben Azzai says, "A man is obligated to teach Torah to his daughter so that if she drinks, she would know that merit is what suspends [the punishment] for her."

R. Eliezer says, "Whoever teaches Torah to his daughter, it is as if he teaches her sexual lust." (M. Sotah 3:4)

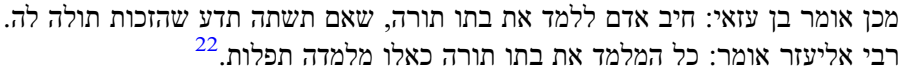

Here Eliezer ben Hyrcanus, a second-generation Tanna, ${ }^{23}$ rejects his younger peer Ben Azzai's ruling that a man could teach Torah to his daughter as a means of ritual protection. ${ }^{24}$ R. Eliezer rejects outright Ben Azzai's suggestion by aligning women's Torah study with תפלות (sexual lust). His association of Torah with lust could derive from the immediate context of the mishnah, where the daughter might be studying adultery-related texts and become inflamed by lust, as Daniel Boyarin argues; alternatively, the association could more broadly exhibit Marjorie Lehman's claim that "some rabbis drew a direct parallel between the notion of women as temptresses and their engagement in Torah study." ${ }^{25}$ In either case, the rabbis associate anxiety about a woman's power of seduction with her potential Torah knowledge. A later passage in tractate Sotah similarly describes a "seductive woman" (אשה פרושה) as one who "sits and lustfully recites words of Torah." ${ }^{26}$ Both study of Torah and lust are conjoined in rabbinic thinking about women's modesty, which explains how a ritualized curse for suspected adultery generates a broader discussion of teaching Torah to women.

21. The Bavli understands the delay in the curse as a chance for the woman to prove her guilt through pregnancy. According to B. Sotah 20b, the merit might suspend punishment for three months, in which case the physical signs of pregnancy would manifest, or for the full nine months, which would fully acquit or condemn her of suspected adultery.

22. Chanoch Albeck, The Mishnah: Seder Nashim (Jerusalem: Mosad Bialik, 1954), 240; Epstein, Mavo' le-nusah ha-Mishnah (Jerusalem: Magnes, 1948), 2:536.

23. Eliezer ben Hyrcanus is known in the Mishnah simply by Eliezer. I follow Strack and Stemberger's genealogy of rabbinic Tannaim: Introduction to the Talmud and Midrash, 69-70.

24. Sarit Kattan Gribetz notes a layer of textual irony, whereby the two rabbis debate the intellectual consumption of Torah by women while the very physical consumption of Torah-represented by the ink from the sotah curse - is unquestioned. Sarit Kattan Gribetz, "Consuming Texts: Women as Recipients and Transmitters of Ancient Texts," in Rethinking 'Authority' in Late Antiquity: Authorship, Law, and Transmission in Jewish and Christian Tradition, ed. A. J. Berkovitz and Mark Letteney (New York: Routledge, 2018), 178-83.

25. Marjorie Lehman, "Rereading Beruriah through the Lens of Isaac Bashevis Singer's Yentl," Nashim: A Journal of Jewish Women's Studies \& Gender Issues, no. 31 (2017): 131; Daniel Boyarin, Carnal Israel: Reading Sex in Talmudic Culture (Berkeley: University of California Press, 1993), 178.

26. Y. Sotah 3:4. 
What is most pertinent for our purposes is the observation that the Mishnah has shifted the focus of the sotah ritual from the person accused of adultery to Jewish women in general, an interpretive move that Rosen-Zvi argues is "undoubtedly framed by the rabbis' thoughts on the nature of women, in its broadest sense." ${ }^{27}$ The matrona story appears among a series of passages responding to the Mishnah that concern women's involvement in Torah study. Immediately preceding the matrona passage, another discussion addresses how and in what capacity women could engage with communal learning. In this text R. Eleazar ben Azariah offers an interpretation of Deuternomy 31:12, which commands the Israelites to assemble all men, women, children, and foreigners (גרים) so that they may "hear and learn to fear" God. ${ }^{28}$ R. Eleazar teaches that on that day, the men came to learn, the women to listen, and the children to "bring reward to the people who brought them." 29 The text emphasizes the role of women as passive listeners rather than active learners. The matrona story appears immediately following and participates in this textual fixation on the proper relationship of women to Torah. In her case, R. Eliezer dismisses the matrona's Torah-related question, retorting that "the wisdom of a woman is only in her spinning rod," drawing a gendered boundary between categorical "women's work" and the masculine task of Torah learning. ${ }^{30}$

In the context of this talmudic preoccupation with women and their Torah knowledge, scholars have raised the question of the function of the matrona in this passage. That rabbinic literature overwhelmingly genders Torah study as a masculine task is without question. In the biblical text, Moses commands fathers to "teach their sons" (Deuteronomy 11:19), and both Talmuds emphasize this gendered distinction by adding, "YYou shall teach them to your sons' to your sons but not to your daughters. ${ }^{31}$ However, rabbinic literature also includes positions of support for the instruction of women and preserves anecdotal examples of women with Torah knowledge - even if such knowledge is occasionally dismissed, as in the case of the matrona. ${ }^{32}$

27. Rosen-Zvi, Mishnaic Sotah Ritual, 231.

28. Y. Sotah 3:4 (19a). See also T. Sotah 7:9.

29. Ravina expresses a similar sentiment in the Babylonian Talmud, arguing that women, while not obligated to study Torah, share in the merit of their sons and husbands' study (B. Sotah 21a).

30. For example, Y. Ketubbot 5:6 (29b) lists the spinning of wool as one of the tasks a woman must perform for her husband's benefit. On the gendered depictions of women weavers in rabbinic literature, see Miriam B. Peskowitz, Spinning Fantasies: Rabbis, Gender, and History (Berkeley: University of California Press, 1997).

31. Y. Berakhot 3:3 (6b); B. Kiddushin 29b, 30a.

32. Tal Ilan compiled a list of examples where women are assumed to know and/or study Torah. See "Study of Torah," in Ilan, Jewish Women in Greco-Roman Palestine. See also Judith Hauptman, "The Talmud's Women in Law and Narrative," Nashim: A Journal of Jewish Women's Studies and Gender Issues 28 (2015): 30-50, and Hauptman, "A New View of Women and Torah Study in the Talmudic Period," Jewish Studies, an Internet Journal 9 (2010): 249-92. David Goodblatt contextualized much of ancient Jewish women's potential Torah knowledge as "household" law, that is, the kinds of teachings a woman could learn from her mother within a rabbinically observant household. David Goodblatt, "The Beruriah Traditions," Journal of Jewish Studies 26 (1975): 83. Daniel Boyarin 


\section{Krista Dalton}

Michael Satlow contends that the matrona in this anecdote functions literarily as a propeller for the rabbis' belief that women categorically do not learn Torah, ${ }^{33}$ writing, "The only point of her question is to serve as a vehicle

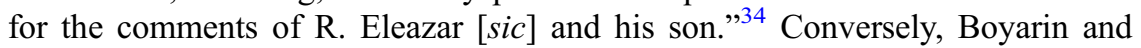
Tal Ilan read the mishnah and related matrona story as a historical possibility, though to different ends. Boyarin reads Ben Azzai's position in the Mishnah as a representation of a small opposition party within the rabbinic movement that supported the inclusion of women in Torah study; thus, the matrona is a literary foil for a broader historical platform. ${ }^{35}$ Ilan, however, disagrees that these texts indicate "dissident voices of opposition within rabbinic culture" and believes that they rather represent "slips of the pen which reflect reality." ${ }^{36}$ For Ilan, the debate over women and Torah reflects the real engagement of women with learning in the ancient world.

These different interpretations of the matrona story reflect a general trend in modern feminist scholarship. Scholars have characteristically pursued one of two goals: either to retrieve lost histories of real women or to analyze the rhetorical construction of women. ${ }^{37}$ These analytical pursuits apply a laser focus to the textual and material record, scanning for relics of gender or its construction. While both approaches have contributed to an expanded understanding of the lives of women in antiquity, they come with their share of challenges. ${ }^{38}$ Attempts to mine for historical kernels will run into the methodological hurdle posed by the scarcity of material records to substantiate scholarly claims. On the other hand, by emphasizing the "rhetorical representation" of women, we forget that men, too, even if the authors of the texts, are rhetorically represented. There is no unfiltered access to the lives of men, just as women are not simply figments of the male textual imaginary.

With such focus on the matrona's gender and its relationship to Torah, an overlooked statement in the passage has escaped analytical notice. R. Eliezer's son, Hyrcanus, responds to his father's dismissal of the matrona in alarm, saying, "in order not to give her an answer you made me lose 300 kors of tithe

finds Goodblatt's observation that this is practical kitchen knowledge implausible. Instead, the women understand religious law. Carnal Israel, 183n16.

33. Satlow, "Try to Be a Man," 35.

34. Ibid.

35. Boyarin, Carnal Israel, 173. He suggests that by countering Ben Azzai's position through R. Eleazar ben Azariah's teaching, "the Palestinian Talmud is accepting Ben-Azzai's statement into the universe of its discourse."

36. Tal Ilan, Mine and Yours Are Hers: Retrieving Women's History from Rabbinic Literature (Leiden: Brill, 1997), 169.

37. See Elizabeth Clark, "The Lady Vanishes: Dilemmas of a Feminist Historian after the 'Linguistic Turn," Church History 67, no. 1 (1998): 1-31.

38. On this point, see the review essay by Ishay Rosen-Zvi, "Misogyny and Its Discontents: Midrash Women: Formations of the Feminine in Rabbinic Literature [by Judith Baskin]," Prooftexts 25, no. 1-2 (2005): 217-27. 
every year! ${ }^{39}$ While this statement is either ignored ${ }^{40}$ or treated as a rhetorical set-up for R. Eliezer's rejection of teaching women, ${ }^{41}$ the exclamation nevertheless assumes that the woman is a donor who expects to engage with Torah study because she feels entitled to the rabbi's expertise. Whether the matrona is operating as a literary foil or not does not diminish the assumption of the authors that such a tithe donor might insert herself into the rabbinic domain. The author imagines that a wealthy woman (a) could have a combative exchange with a rabbi over Torah and consequently (b) could affect the tithe donations a rabbi's family receives. In this case, the anxiety within this story is less simplistically about "what do we do if a woman wants to engage in Torah?" than "what do we do when a donor who is also a woman both engages in talmudic thinking and expects a rabbi to respond with his expertise as if she were a student?"

Another clue that class and economic power are significant to the story derives from a textual parallel. When this story appears in the Babylonian Talmud, every aspect of the matrona's class and status is stripped from the text. ${ }^{42}$ No longer is she a matrona, but she is rather a "wise woman" (אשה חכמה). Hyrcanus's protest at the loss of tithes and R. Eliezer's harsh retort are absent. It may be the case that R. Eliezer's resistance to the matrona and her resulting tithe removal was either unimportant to, ignored by, or unknown to the Babylonian academy, but in the case of the Jerusalem Talmud the woman's status as a donor is a foundational aspect of the story. Hyrcanus is hyperaware of the social codes broken by his father's dismissal of her question and the resulting loss of a valuable tithe. By shifting analysis to the matrona's economic position and agency, her relationship with R. Eliezer transforms from just a stereotypical gendered clash to one of a strained donor relationship.

Susan Marks, in her study of Rabbi Akiva's wife, similarly demonstrates how rabbinic texts struggle with recognizing her role as Akiva's patron. His wife is said to have sold "the very braids on her head" to fund his Torah study, ${ }^{43}$ yet Marks identifies how the text goes to great lengths to limit her financial capacity. ${ }^{44}$ Further, scholarship has focused on her role as an "ideal woman" or "fantasy wife," to which Marks asks, "When is the story of a famous patron not the story of a famous patron? Answer: when the patron is a woman, and when acknowledging her patronage risks reifying her power to affect the substance of

39. Magen Broshi, "Agriculture and Economy in Roman Palestine: Seven Notes on the Babatha Archive," Israel Exploration Journal 42, no. 3/4 (1992): 230-40, uses the Babatha documents of sale from palm groves to approximate ancient Judean units of measurement, including the kor: "A bet se'ah (the area of sowing a se'ah), according to a Talmudic source, is 50 x 50 cubits (a beraitha quoted in BT Erub. 23b). In modern metric terms, bet se'ah is $625 \mathrm{~m} .2$; bet kor 30 times bigger: 18,750 m.2; and bet qab a sixth of a bet se'ah: 104 m.2."

40. Labendz, Socratic Torah, 108; Ilan, Jewish Women in Greco-Roman Palestine, 191.

41. "Matrona is used as a foil. Her question, which this text itself admits is a good one, is derisively dismissed." Satlow, "Try to be a Man," 35.

42. B. Yoma 66b.

43. Y. Shabbat 6:1 (7d).

44. Marks, "Follow That Crown," 78-80. 


\section{Krista Dalton}

the study that her money makes possible. ${ }^{, 45}$ The case of Rabbi Akiva's wife represents another example where rabbinic literature both acknowledges the role of women as donors to the cause of Torah study but textually qualifies their gift.

Recognizing that tractate Sotah is a textual site for managing the threats of women broadly, Hyrcanus's anxiety attests to an undercurrent of clashing social expectations in the encounter. In practice, men and women are never so easily reduced to just their gender identity. They are actors within a broad social nexus of intersecting identities and experiences, each with a different relationship to structural power. ${ }^{46}$ The matrona is a wealthy elite with some measure of influence over the distribution of agricultural goods, who uses her power to engage in rabbinic Torah study, a threat compounded by her gender. Here in tractate Sotah this threat is managed by the textual power of R. Eliezer's searing insistence that the words of Torah would be better burned than relinquished to the matrona.

\section{Rabbinic Anxiety of Patronage and Donors}

After their encounter, the matrona abruptly leaves and Rabbi Eliezer's students ask him to answer her question: "Rabbi, this one you pushed away with a stick, but what would you explain to us?"47 While one might have thought his dismissal of the matrona was an appropriate response to a seemingly bad question, the text concedes that it is in fact a worthy line of inquiry. Therefore, the threat of the matrona was not in the substance of her question but in that question's threat to rabbinic expertise. The matrona physically entered rabbinic study space, attested by the spectacle of their exchange witnessed by rabbinic students, and she modeled rabbinic logic. Nor was she a neutral party, but as a tithe donor she expected access to rabbinic expertise. Her presence shattered the idyllic representation of rabbinic autonomy with the reality of the rabbinic dependence on social networks. Rabbi Eliezer constructed a rhetorical boundary between himself and the matrona on the basis of her gender so as to mask her power as a donor. The literary trope deployed by his students ("this one you pushed away with a stick") ushers the matrona's question into the safety of their scholarly circle. ${ }^{48}$

There are a number of potential explanations for this anxiety of donors. First, donors presented a threat of encroachment on scholarly autonomy, as seen in the matrona's invasion of Rabbi Eliezer's scholarly domain. Donors and scholastic experts walked a tenuous line - on the one hand, scholars held specialized knowledge inaccessible to the public; patrons, on the other hand, had material and social capital. The donor's power threatened to destabilize the scholars' presumed autonomous authority. In order to effectively compete, ancient scholars

45. Ibid., 77.

46. Pierre Bourdieu, Outline of a Theory of Practice (Cambridge: Cambridge University Press, 1977).

47. רבי לזר דחיתה בקנה לנו מה אתה משיב. On the use of this phrase in rabbinic literature, see Labendz, Socratic Torah, 101-20.

48. This trope is often used whenever a (presumable) gentile asks a rabbi a question. See Y. Shabbat 3 (6a); Yom Tov 2:5 (61c); and Pesiq. Rab Kah. 4:7. 
strove to project an aura of "expertise" through tactics of legitimation, which deflected attention away from donor influence. Anthropologist Jeremy Boissevain framed these types of relationships as situational, whereby patrons and clients defined their social roles and their resulting anxieties through continual performance. $^{49}$ Expertise, therefore, was not self-evident; it had to be performed and required validation from others even if that validation brought uncomfortable obligations.

Kendra Eshleman's analysis of the Second Sophistic pepaideumenoi (orators and philosophers) and their patrons offers a meaningful point of comparison. Eshleman describes a "cognitive dissonance" maintained by philosophers in order to balance the scales of donor power. She argues that the pepaideumenoi must "simultaneously tower above elite imperial society as moral critic and/or embodiment of its highest cultural aspirations, while also competing for students and status at the disposal of that society." to their own social networks and donors operated on similar grounds. In the example of Rabbi Eliezer and the matrona, we can see the inartful balancing of social reciprocity. It may very well have been less than ideal for a woman to engage in rabbinic study methods, but her donor habits certainly convinced Hyrcanus of her right to participate. Rabbi Eliezer manages her donor expectations with the invocation of an authoritative proof text from Exodus to speak for him, justifying his dismissal with the Torah's conjoining of women's wisdom with spinning rather than study.

This suspicion of donors was further buttressed by a general rabbinic wariness of Greco-Roman patronage. The rabbis both criticized patronage and defined themselves through their own discipline's autonomy to wider society at the same time as they operated within an embedded place in the networks of donors. Patronage was a system of asymmetrical relationships forming an extended, and often long-term, system of transactions exchanged between two parties. ${ }^{51}$ These relationships took a variety of forms in the Roman imperial world, including between land owners and tenants, wealthy elites and scholars, and even between the emperor and the citizen body. Donations could come in the form of benefaction (euergetism), which expected civic leaders to personally finance the building of monuments, city centers, and festivals in exchange for their privileged position, ${ }^{52}$ or as individual personal gifts. While each example of patronage is localized and contextual, its reciprocal logic was a constant

49. Jeremy Boissevain, Friends of Friends: Networks, Manipulators and Coalitions (New York: St. Martin's Press, 1974).

50. Eshleman, Social World of Intellectuals in the Roman Empire, 89-90.

51. Richard Saller contends that as a state administration expands, providing services and protections for citizens, the need for patrons declines. He defined a patronage relationship with three defining features: reciprocal exchange, long-term relationships, and asymmetrical status between the patron and client. Personal Patronage under the Early Empire (Cambridge: Cambridge University Press, 1982), 1-3.

52. Paul Veyne, Bread and Circuses: Historical Sociology and Political Pluralism, trans. Brian Pearce (London: Penguin, 1990). 


\section{Krista Dalton}

social understanding, as Ernest Gellner insists, “"Real' patronage seems to me to be a system, a style, a moral climate. ${ }^{, 53}$ One did not need to state the expectations of reciprocity, it was understood by each participant in the transaction.

The rabbis, however, were not passive adherents to Roman values. Part of the rabbinic project was a commitment to the Torah and their particular form of Jewish piety, which distinguished the Jews - as they claimed - from the Romans. ${ }^{54}$ The rabbis instructed ancient Jews to avoid Roman circuses and games, to distinguish themselves from Roman manners and customs, and to seek rabbinic judicial authority rather than the Roman courts. ${ }^{55}$ Rabbinic literature goes to such great lengths to present the Romans as Others, as Seth Schwartz insists, that "they told story after story about how right the Torah was and how wrong the Romans were." ${ }^{56}$ Systems of patronage, in particular, were heavily criticized for the abuse and limits of the patrons' power. ${ }^{57}$ A series of homilies in Y. Berakhot 9:1 (13a), for example, depict a patron as aloof; when his client is on the brink of death, the patron is nowhere to be found. The Holy One, by contrast, stands by his client's side and rescues him from calamity. Yet, just as the rabbis expressed ardent Jewish distinctiveness, in the same breath their stories reflect an accommodation and even internalization of some Roman values. ${ }^{58}$ The rabbis themselves, while critical of patronage debt relationships, preserve accounts of their own wealthy benefactors. For example, R. Eliezer, R. Yehoshua, and R. Akiva are said to have made regular visits to Antioch in order to fundraise. ${ }^{59}$ The matrona passage fits within this pattern of accounts of rabbinic donor networks.

A second point of anxiety concerns the nature of the matrona's donation. Her gift is called ma'aser, or tithe, which might lead us to assume an ideal relationship between a Jew and a priest-in fact, this source is often cited as evidence for R. Eliezer's priestly descent. ${ }^{60}$ The Pentateuch prescribes that the Israelites should leave a portion of their agricultural produce to the priests and Levites. Setting aside a tithe of the harvest in order to finance the services of temple personnel and royal administrators was common throughout the ancient Near East, ${ }^{61}$ and functioned as

53. Ernest Gellner, "Patrons and Clients," in Patrons and Clients in Mediterranean Societies, ed. Ernest Gellner and John Waterbury (London: Duckworth, 1977), 3.

54. Hayim Lapin, Rabbis as Romans: The Rabbinic Movement in Palestine, 100-400 CE (Oxford: Oxford University Press, 2012), 126.

55. Beth Berkowitz, Defining Jewish Difference: From Antiquity to the Present (Cambridge: Cambridge University Press, 2012).

56. Schwartz, Were the Jews, 114.

57. See Daniel Sperber, "Patronage in Amoraic Palestine (C. 220-400): Causes and Effects," Journal of the Economic and Social History of the Orient 14, no. 3 (Dec 1971): 227-52.

58. Schwartz, Were the Jews, 116.

59. Y. Horayot 3:7 (48a); Vayikra Rabbah 5:4.

60. Though this text does not provide enough evidence for that claim.

61. Moshe Weinfeld, "Tithes," in Encyclopedia Judaica 15 (1971): 1156-62; Marty E. Stevens, Temples, Tithes, and Taxes: The Temple and the Economic Life of Ancient Israel (Grand Rapids, MI: Baker Academic, 2006); Fabian Udoh, To Caesar What Is Caesar's: Tribute, Taxes and Imperial Administration in Early Roman Palestine (63 BCE-70 CE) (Providence: Brown Judaic Studies, 
a kind of obligatory tax necessary for the maintenance of cultic centers. ${ }^{62}$ Three primary passages in the Torah make up the contours of the tithe, but their language is quite vague. Numbers 18 insists that God gave every tithe of Israel to the Levites as their inheritance. From this tithe portion, the Levites were instructed to separate a tithe specifically for the Aaronic priests. By comparison, Leviticus 27:30-33 stipulates that all tithes from the land and every tenth of the flock should be "holy to the Lord." While Leviticus directs the tithing of produce and animals, it keeps its recipient vaguely "to the Lord" rather than naming the priests or Levites explicitly. In Deuteronomy 14, farmers are instructed to tithe yearly from their agricultural produce and consume the food in a place designated by God (Deuteronomy 14:22-26). This tithe was to be shared with the Levites and accompanied by a verbal recognition that the land's fertility was directly tied to God's protection (Deuteronomy 26). Every third year - that is, every third and sixth year of the Sabbatical cycle-farmers were also to give a special tithe to the Levites, foreigners, and the needy (Deuteronomy 14:29).

Throughout the Second Temple period, writers consolidated the disparate biblical traditions into orderly systems. In the books of Jubilees and Tobit, Deuteronomy's calendar cycle appears as three separate tithes given every year of the harvest-gleaning years (years 1-6): a tithe consumed by the farmer, a tithe apportioned to the Levites and priests, and a tithe for the poor. ${ }^{63}$ Josephus echoes these three distinct tithes, though limits the tithe for the poor to the third years (years 3 and 6). ${ }^{64}$ The early rabbis formalized these tripartite categories into the ma'aser rishon, or the "first tithe" for Levites; ma'aser sheni, or the "second tithe" to be consumed by the householder in Jerusalem; and the ma'aser "ani, or the "poor tithe." 65 The macaser rishon encompassed two related measures: first a portion designated for the Levitical class, and second a fraction

2005). Compare with Peter Fawcett's work on religious taxes in classical Athens. "When I Squeeze You with Eisphorai': Taxes and Tax Policy in Classical Athens," Hesperia: The Journal of the American School of Classical Studies at Athens 85, no. 1 (2016): 153-99.

62. For an alternative reading of tithes as gifts rather than taxes, see Menahem Herman, Tithe as Gift: The Institution in the Pentateuch and in Light of Mauss's Prestation Theory (San Francisco, CA: Edwin Mellen Press, 1991).

63. Scholars disagree about the exact number of tithes represented by these two systems. E. P. Sanders describes Tobit as reflecting a fourteen-tithe system, that is, three tithes every year but the seventh. However, Fabian Udoh suggests Tobit follows an eighteen-tithe system, giving a tithe to the Levites, expenditure in Jerusalem, and the poor in each of the six years of the Sabbatical cycle. By comparison, Jubilees designates a yearly tithe to the Levites/priests and a yearly tithe to be consumed in Jerusalem, representing a twelve-tithe system. Sanders suggests that the tithe for the poor is assumed in Jubilees, and thus would represent either a fourteen- or eighteen-tithe system: E. P. Sanders, Judaism: Practice and Belief, 63 BCE-66 CE (Grand Rapids: Fortress Press, 2016), 149; Fabian Udoh, To Caesar, 247.

64. This represents a fourteen-tithe system.

65. Rabbinic literature assumes the existence of the priestly tithe, though we do not know the extent of tithing practices in the rabbinic period. Lee Levine, The Rabbinic Class of Roman Palestine in Late Antiquity (New York: Jewish Theological Seminary of America, 1989), 71; Michael Satlow, "Markets and Tithes in Roman Palestine," in Gift-Giving and the Embedded Economy in the Ancient 


\section{Krista Dalton}

of the Levitical portion reserved for the priests, called terumah. ${ }^{66}$ However, the opacity of an exact tithing system likely led to a variety of tithing practices, ${ }^{67}$ as Fabian Udoh, in his summary of the types of strategies for tithing harmonization, concludes: "In actual practice individuals would have chosen the [tithing] system that corresponded to their piety, group affiliation, and economic capabilities. ${ }^{68}$ Despite this flexibility, Jews who desired to display piety would have calculated tithing into the management of their household resources. ${ }^{69}$

Following the Temple's destruction in $70 \mathrm{CE}$, members of wealthy priestly families joined with burgeoning rabbinic study circles, coming to embody the dual identities of priest and rabbi. ${ }^{70}$ Their relationship to the now-defunct Temple system was in question, specifically whether they were entitled to benefit from tithes. While the Torah designated the Levitical and priestly tithe as a kind of obligatory tax - enforced by conquering emperors and granted as a de iure right under Julius Caesar - there were no designated communal funds for the rabbis. Their guild was defined by expertise in Torah. Yet the Temple's destruction tested the logic of tithing - why should one tithe to priests if they no longer served a cultic function? The administrative function of sacrifices was gone, yet priests and Levites could still claim the tithe as an inheritance right.

It appears that some people may have continued to give tithes to priestly descendant rabbis, but why they did so was reframed in terms of expertise rather than priestly descent:

R. Yonah gave his tithes to R. Aha bar Ulla, not because he was a priest but because he studied Bible. What is the reason?: "He said to the people, the inhabitants of Jerusalem, to give the part of the priests and the Levites, so

World, ed. Filippo Carlà and Maja Gori, Akademiekonferenzen 17 (Heidelberg: Universitätsverlag Winter, 2014), 315.

66. See B. Yevamot 86b, Sotah 47b, and Hullin 131b for rabbinic explanations for the shift of the Levitical tithes to the priests.

67. Udoh reminds us, "The disagreement in the sources about the 'types' of tithes should make us wary of suggestions that any particular legislation 'reflects' the totality of actual practice." To Caesar, 249.

68. Ibid., 248.

69. See Alexander Ramos, "Torah, Temple, and Transaction: Jewish Religious Institutions and Economic Behavior in Early Roman Galilee" (PhD diss., University of Pennsylvania, 2017), 11, for analysis of Galilean piety and the Temple economy. Ze'ev Safrai concludes that Jews abroad were often inclined to observe tithes even though they were nonobligatory, in The Economy of Roman Palestine (New York: Routledge, 2003), 381.

70. For lists of rabbis with priestly descent see Adolf Büchler, Die Priester und der Cultus im letzten Jahrzehnt des jerusalemischen Tempels (Wien: Hölder, 1895), 7-47; Seth Schwartz, Josephus and Judaean Politics (Leiden: Brill, 1990), 100-101; Catherine Hezser, The Social Structure of the Rabbinic Movement in Roman Palestine (Tübingen: Mohr Siebeck, 1997), 70-71. Dalia Trifon calculates that roughly 40 percent of attested Palestinian sages during the Yavneh period were priests (though such estimates are difficult to pinpoint with the limited sources we have). Dalia Ben Haim Trifon, "The Jewish Priests from the Destruction of the Second Temple to the Rise of Christianity" [in Hebrew] (PhD diss., University of Tel Aviv, 1985), 175, 188-89. 
they should be strong in the Torah of the Eternal" [2 Chronicles 31:4]. R. Huna did not take a tithe, R. Aha did not take a tithe. R. Hiyya bar Ba instructed himself to go outside the Land of Israel, so as not to take a tithe. He asked R. Samuel bar Nahmman who asked R. Yonatan, "May one take?" He said to him, "Take! What fell to your tribe fell to you." (Y. Ma'aser Sheni 5:5 [56b])

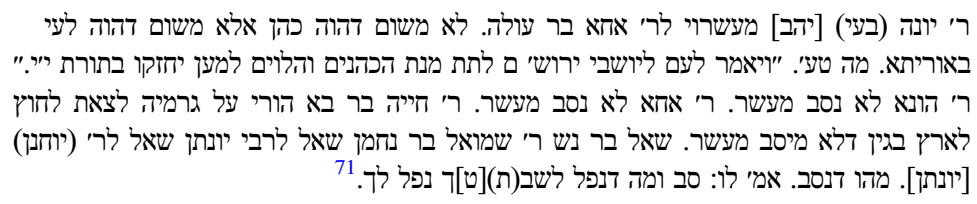

Here R. Yonah argues that the actual reason priests and Levites received tithes was because they were purveyors of Torah, and priestly descendent rabbis should continue to receive tithes because they are the new purveyors of Torah. By this logic rabbis were receiving tithes for the expertise of their rabbinic office and not because of their priestly descent. This preference for scholastic over genealogical status appears early in the Mishnah when a mamzer, or child of an adulterous union, who is a disciple of sages is said to take precedence over a high priest who is unlearned. ${ }^{72}$ Shifting the logic of tithing to favor expertise over cultic office provides the context for how a woman like the matrona might give tithes to a priestly descendent rabbi like Rabbi Eliezer. But shifting the logic for the transaction - from tax to donation - imbued the tithe with a distinct set of cultural expectations. The matrona passage assumes and fears that a tithe donor might expect reciprocal attention from her chosen client.

This expectation of reciprocity explains why the passage lists the names of rabbis who refused to take the tithe, in particular R. Hiyya bar Ba, who is said to have fled the region in order to avoid taking a tithe. R. Hiyya's complicated relationship with the priestly tithe is preserved in more detail in Y. Shevi it 3:1 (34b). Shevi it opens with a discussion regarding when a farmer may pile manure into dung heaps in order to fertilize the following year's harvest during the Sabbatical year. Silanus, ${ }^{73}$ a rich landowner, asks R. Hiyya bar Ba whether he could pile the dung earlier in the year. The text insists that R. Hiyya bar Ba forbade Silanus. But then the text reveals that R. Hanina thought that R. Hiyya bar Ba did allow Silanus to get a head start on field fertilization. The people suggested that R. Hiyya favored Silanus because Silanus was giving him tithes. To avoid suspicion of bending the law to please a donor, the text insists R. Hiyya bar Ba returned to Babylonia and thus avoided profiting from Silanus's yields.

The exchange between R. Hiyya bar Ba and Silanus provides an illuminating comparison for the matrona's tithe. Both Silanus and the matrona expected a

71. Sussmann, Talmud Yeruhslami, column 307.

72. M. Horayot 3:8.

73. Silanus is a cognomen of the gens Junia and was associated with a noble Roman family who rose to prominence in the early first century CE. 


\section{Krista Dalton}

rabbi to use his specialized knowledge of Torah on their behalf as part of a reciprocal exchange connected to the tithe gift. These anecdotal accounts - preserved for other contextual purposes (field fertilization in Sheviit; women's Torah study in Sotah) - depict priestly tithes given to the new categorical recipient of rabbinic scholars introduced in tractate Ma'aser Sheni. This is not to say that tithes given to priests in the Second Temple period did not have the capacity to generate reciprocal relationships, but tithes given to priestly descendent rabbis appear to have invoked the reciprocal expectations of late antique aristocratic patronage and triggered tactics for negotiating those tensions.

The naming of the matrona's gift as a tithe does not appear without some measure of strategy - if she were but fulfilling a covenantal obligation of taxation by giving her tithes to a priest, she would have no claim to reciprocity from the priest. ${ }^{74}$ The tithe-gift relationship was between the priest and God, while the Israelites served as the mediators of transfer. ${ }^{75}$ However, the fact that the matrona withdraws her tithes after R. Eliezer refuses to instruct her in Torah suggests that the tithe in this story is perceived as a reciprocally informed donation. The matrona is not named explicitly as a patron, and if it were not for Hyrcanus's protest we might not have thought of her tithe as anything but a tithe. But when a designated inheritance portion for Levites based on genealogical claims transitioned to the explicit funding of rabbinic study, the transaction invoked the logic of reciprocity. Rabbinic anecdotal accounts reflect the anxiety of this logic and the kinds of fraught relationships it might generate.

A final point of anxiety in the matrona passage is the general rabbinic wariness of appearing to profit from Torah. In Mishnah Avot we learn that Hillel, one of the earliest rabbinic sages and founder of a legendary dynasty of scholars, taught that the Torah should not be used as a means for income. "He who makes worldly use of the crown shall perish," he says, to which the editorial voice explains, "From this you learn: He who uses words of Torah for his own benefit removes his life from the world." Elsewhere in the Jerusalem Talmud, the tension of teaching Torah and profit is addressed through the figure of Moses. He is upheld as a model Torah scholar who taught the Israelites free of charge (בחינם), ${ }^{76}$ but he is also remembered as extremely wealthy. The relationship between wealth and Moses's character is the subject of some debate:

74. This is not to say that tithes given to priests in the Second Temple period did not in practice activate reciprocal expectations, but rather that the Torah's ideal would hope that there was no claim to reciprocity.

75. The Israelites were instructed to set aside a tithe of their harvest as a symbolic gift (terumah) to God, which he then allotted to the landless Levitical and priestly class. In Numbers 18:19-32, God says to Moses: "To the Levites I have given every tithe [ma'aser] in Israel for an inheritance in return for the service that they perform, the service of the tent of meeting" (v. 21). In this formulation, God facilitated the transfer of the tithe from the Israelites to the Levites, rendering the people's tithe gifts into the Levites' own possession.

76. Y. Nedarim 4:3 (38c). 
R. Hamma b. R. Hanina said: Moses got rich from the chips of the tablets. That is what is written, cut for yourself two stone tablets [Exodus 34:1]. Cut for yourself: the chips shall be yours. R. Hanina said, The Holy One blessed be He created ${ }^{77}$ a quarry of precious stones and pearls in his tent, and from this Moses got rich. As it is written, they looked after Moses until he reached the tent [Exodus 33:8]. Two Amoraim [disputed the meaning of "looking"]: One said it was meant unfavorably and the other that it was meant favorably. He who thought unfavorably, says: "Look at the thigh, look at the feet, look at his flesh. He eats from the Jews, drinks from the Jews, everything he has is from the Jews." He who thought favorably, says, "To simply look upon the just is meritorious [meritorious for the one who sees him]." (Y. Shekalim 5:3(2) [49a])

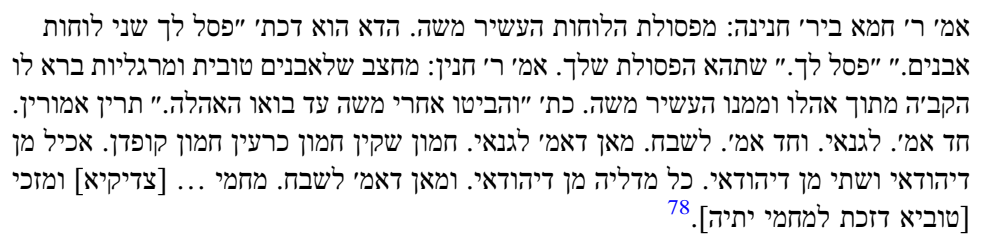

This passage begins with the assumption that Moses was quite wealthy and that this wealth comes into question. R. Hamma bar Hanina explains that Moses derived benefit from his role in the giving of the Law-following the destruction of the first tablets, God commanded Moses to cut two tablets from stone, made presumably, in this interpretation, from precious stones. The "leftovers" from the chiseling made Moses wealthy. R. Hanina offers a relatedly generous suggestion that God provided a gem-filled quarry in Moses's tent. Both explanations attribute Moses's wealth to divine providence. However, the interjection of a proof text provides an occasion to visit an associated amoraic dispute, which appears in a different context in Y. Bikkurim 3:3 (65c). ${ }^{79}$ One anonymous Amora suggests that Moses was entirely sustained-in perhaps excessive amounts - by the Israelites' donations. This interpretation assumes that Moses, as the bearer of Torah, profited from his position. Remarkably, the assumption that Moses would be entirely sustained by communal support is the unfavorable reading, contradicting the rabbinic ideal of Torah scholars devoting their entire attention to Torah. This passage recognizes the kinds of ill speech that might circulate in society when scholars sustain their livelihoods from donations.

This worry of dependence and profit is sharply displayed in both the stories of R. Hiyya bar Ba and the matrona. R. Hiyya fled the region so as not to appear to profit, and Rabbi Eliezer insists that the words of Torah are better burned than

77. British Library manuscript Or 2822 states that God uncovered the gems within the tent: גלה לו הבה למשה מתוך אהלו (f. 350v; 651).

78. Sussmann, Talmud Yerushalmi, column 621.

79. This parallel appears in Y. Bikkurim 3:3 (65c) in the context of determining when one rises before an elder. In this case, two Amoraim debate whether people rose in Moses's presence in order to acquire merit or in order to slander him. Compare with B. Kiddushin 33b and Tanhuma Ki Tissa 26. 


\section{Krista Dalton}

given to a woman, even a woman who donates tithes. These texts highlight the rabbinic apprehension of a Torah scholar's relationship to wealth, whether through the appearance of profit and luxury or in the power of donations to influence the rabbinic office. In each of these scenarios, it is better to go to extreme lengths than to generate rumors of profit.

By situating the matrona text alongside other anecdotal examples of tithing to rabbis, we can observe how tithes and other donations might be given with the expectation of receiving a benefit from rabbinic expertise. In the case of R. Hiyya bar $\mathrm{Ba}$, he entered a financial relationship with a wealthy landowner, who at least hoped R. Hiyya's rulings would err in his favor. In the matrona text, the matrona expected an answer from a rabbi notorious for his stance against teaching Torah to women.

\section{Scholastic Donors in the Ancient Mediterranean}

Donating to the production of knowledge was an attractive investment for patrons in the late ancient Mediterranean. Aristocratic families had long been powerful social entities, forming friendships through the transfer of gifts, with a keen eye to self-promotion. By aligning themselves with individual scholars, as well as institutional structures of expertise, their gifts created an avenue for influence that generated social and cultural capital. Rabbis cultivated their scholastic expertise within this culture of relationship building familiar to influential families across the Roman Empire. Therefore, while ambivalent themselves about the merits of patronage, their donors understood the expectations that accompanied their gift- even the framing of a donation as a tithe could not wrest the gift from its networks of reciprocity.

A similar phenomenon appears in the Christian setting. As the work of Irene SanPietro has shown, bishops drew from the vision of the Jerusalem Temple's priesthood and extended the metaphor of Levitical tithes to their office. Using the language of tithes, bishops encouraged laity to channel their gifts through the church rather than at their own discretion. ${ }^{80}$ The imperative to tithe took on the imperative to give to the church and its whole host of needs, funding everything from feeding the poor, supporting bishops, and the building of churches. Donors were not simply friends of bishops, but as Kim Bowes has demonstrated, "they were their competition," cultivating self-promotion through patronage networks. ${ }^{81}$ Elite founders of churches, for example, claimed an ownership of those spaces as a natural extension of their authority over their households. Their gifts, they thought, ought to provide them special access and control over the church's operations. ${ }^{82}$ Bishops, by contrast, claimed authority over the

80. Irene SanPietro has shown how this logic proved an effective means of mandating Christian giving in a predictable manner that individual charitable gifts could not manage. "Money, Power, Respect: Charity and the Creation of the Church" (PhD diss., Columbia University, 2014), 76-90.

81. Kim Bowes, Private Worship, Public Values, and Religious Change in Late Antiquity (Cambridge: Cambridge University Press, 2018), 219.

82. Peter Brown, Through the Eye of a Needle: Wealth, the Fall of Rome, and the Making of Christianity in the West, 350-550 AD (Princeton, NJ: Princeton University Press, 2013), 245-58. 
church as an extension of their episcopal appointment, which they saw as the superior claim.

The rabbis also experienced this expectation from building benefactions. In order to acknowledge customary benefactive honors while also maintaining their autonomy and particular ideals, rabbis emphasized their expertise in Torah along with public recognition:

\section{R. Hiyya bar Ba held a fundraiser for a certain house of study at Tiberius. There was one there of the family of Bar Silanus, who pledged a pound of gold. He took him, had him sit with him, and recited for him this verse: $A$ man's gift eases his way. (Y. Horayiot 3:7 [48a])

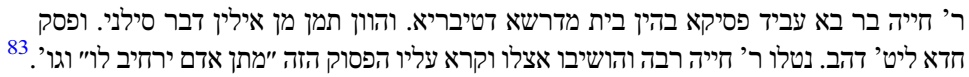

A member of the Silanus family donated on behalf of the rabbinic study house in Tiberius. The rabbis honored him by seating him in a seat of honor. Such a seat of honor is attested in a Greek inscription from Phocee from the third century CE that honors Tation, daughter of Straton son of Empedon. After donating from her own funds to the construction of the assembly hall and courtyard, she is given a "golden crown and the privilege of sitting in the seat of honor." ${ }^{\circ 4}$ In this Jerusalem Talmud text, not only do the rabbis seat the donor in honor, they recite over him the proverb, "A man's gift eases his way and gives him access to great men" (Proverbs 18:16). They interject with a biblical proof text, publicly reminding all spectators of their expertise. Their choice of proof text is further illuminating. Here the rabbis remind generous donors - without very much modesty - that the donor is honored for supporting such esteemed "great men."

While the expectations of reciprocity certainly informed religious gifts, donors also gave because they sought a channel for religious devotion. In exchange for their gifts, pious persons received attention from their religious experts, as Jerome, the fourth-century monastic scholar, remarked to a patron, "You send us gifts, we send you back letters of thanks," 86 letters filled with religious instruction. Donors could delight in the personal satisfaction of the knowledge acquired through individual study. Jerome elsewhere writes of his donor Paula, who learned Hebrew with "zeal" so as to sing psalms in the original. ${ }^{87}$ In this way, donations cultivated a posture of piety. Nor were the benefits of

83. Sussmann, Talmud Yerushalmi, column 1428.

84. Ameling, Inscriptiones, inscription 36 equals Lifshitz 13 equals CIJ 738; translation in Ross Shephard Kraemer, ed., Women's Religions in the Greco-Roman World (New York: Oxford University Press, 2004), 163, 661. For analysis of this inscription, see Marks, "Follow That Crown," 86.

85. מתן אדם ירחיב לו ולפני גדלים ינחינו, Proverbs 18:16, quoted in Y. Horayot 3:7 (48a) and Vayikra Rabbah 5:4.

86. Jerome, Epist. 44.1: "Vos dona transmittis, nos epistulas remittimus gratiarum." All references to Jerome's letters adapted from Jerome and F. A. Wright, Select Letters of St. Jerome (Cambridge, MA: Harvard University Press, 1975).

87. Jerome, Epist. 39.1. 


\section{Krista Dalton}

donor networks one-sided. Religious experts made use of their friends' gifts in a whole host of tangible ways, framed as part of their religious devotion. Funds contributed to the material production of texts, such as buying papyrus or parchment, to the building of personal libraries, and even to the hiring of stenographers to take dictation and assistants to read over drafts. Social networks assisted with the dissemination of materials and spread the word of an individual scholar's acumen, all to the glory of God.

These pious donor relationships and their tensions are aptly described by Jerome. He writes with envy that a friend supplied Origen, the famed ascetic scholar from an earlier century (184-253 CE), with "parchment, money, and copyists," which allowed him to produce "innumerable books." ${ }^{\prime 8}$ Jerome describes their donor relationship as one of intimate meditation: "Day and night it was their habit to make reading follow upon prayer, and prayer upon reading, without a break." 89 Jerome, envious of his idyllic description of Origen's donor relationship, writes longingly to Marcella, his friend and scholar in her own right, who helped facilitate contacts with wealthy donors, about the robust life of the pious mind facilitated with donations. And yet, he ends the letter embracing poverty in this life in exchange for the kingdom of heaven: "Assuredly, when we have found such wealth in heaven, we may well grieve to have sought after poor passing pleasures here on earth." 90 Jerome simultaneously longs for the amicable donor relationship while ultimately elevating his ascetic impulse. While Jerome provides a glimpse into the affective realm of scholastic expertise, complete with its dissonant ideals, patron support ultimately was a necessary partner to a scholar's specialized discipline of study. Scholars, in turn, could claim authority over religious knowledge by virtue of their technical skills and serve as a source of inspiration for their patrons. A feedback loop of recognition and devotion was maintained through the giving of gifts.

Not only can we situate the anecdotal accounts of rabbis and donors within this broader landscape of giving, but the matrona herself fits with a pattern of involvement from women donors in this period. Even though ancient authors extolled the virtues of the domestic wife - quiet, chaste, modest, and excluded from public office - women actively participated in Roman patronage networks. ${ }^{91}$ Inscriptional evidence at Pompeii, for example, shows that women managed businesses and estates, served as public benefactors and patrons, and even participated in moneylending and trade. Writing of the inscriptional evidence at Pompeii, Ramsay Macmullen insists: "At both the top and the bottom of society, women thus appear to take an active part in the common business of the city, at the former level because among them could be found, at the least, a lot of money and the ability to bestow it in one form or another on those who sought it

88. Jerome, Epist. 43.1.

89. Ibid., "Hoc diebus egisse vel noctibus, ut et lectio orationem susciperet et oratio lectionem."

90. Ibid., "Quo scilicet, cum tanta reppererimus in caelo, parva et caduca quaesisse nos doleamus in terra."

91. See Emily A. Hemelrijk, "Patronesses and 'Mothers' of Roman Collegia," Classical Antiquity 27 , no. 1 (2008): 115-62. 
through their offers of flattery, respect and support; at the latter level, because women obviously wanted to take a part and no one told them it was useless or ridiculous." $" 92$

Emily Hemelrijk's work has further illuminated the role of women as patrons and benefactors in imperial Rome. ${ }^{93}$ Hemelrijk observes that because women were at times inhibited with respect to legal or political support, their primary means of patronage participation came through "material rewards and literary encouragement." 94 Women wanted to participate in the culture of their city and leveraged their wealth toward the cultivation of social networks, especially in support of literary expertise. ${ }^{95}$

For Christian women, their gifts were deeply personal; as Elizabeth Clark recounts, "patronage was among the few ways by which women, at least the well-to-do, could leave their mark on Christian life."96 Women like Paula, Melania the Elder, and Olympias founded monasteries. Widows, in particular, had an expanded capacity to use their wealth, and their funds often found eager homes in the hands of Christian scholars. ${ }^{97}$ Jerome, who relied heavily on the support of widows to finance his work, was highly critical of widows who used their wealth ostentatiously for impious endeavors, decrying that "they ride in their roomy litters with a row of eunuchs walking in front." 98 Instead, Jerome petitioned his donors to give generously so as to support both the poor and his scholastic efforts. Mathew Kuefler contends that this critical instruction for widows was crafted in response to their growing economic power as "patrons to churches and churchmen." 99 The rhetoric of support for Christian scholars came part and parcel with the larger appeals for donors to finance Christian institutions, and wealthy women were a particular opportunity for financial support.

Jerome's relationship with his donor Paula, the widow from Rome, is a useful comparison to the rabbinic story of Rabbi Eliezer and the matrona. Jerome spent much of his life traveling between Antioch and Rome, later retiring to Bethlehem. He embodied the contradictory postures of both monk and scholar, cultivating

92. Ramsey MacMullen, "Woman in Public in the Roman Empire," Historia: Zeitschrift für alte Geschichte H. 2 (1980): 210.

93. Emily A. Hemelrijk, Hidden Lives, Public Personae: Women and Civic Life in the Roman West (Oxford: Oxford University Press, 2015).

94. Emily A. Hemelrijk, Matrona Docta: Educated Women in the Roman Élite from Cornelia to Julia Domna (New York: Routledge, 2002), 101.

95. Hemelrijk, Hidden Lives, 344. Hemelrijik concludes, "Rather than being a marginal group or exceptions to the rule, locally prominent women and their civic contributions formed a structural element of Roman urban life."

96. Elizabeth Clark, "Patrons, Not Priests: Gender and Power in Late Ancient Christianity," Gender \& History 2, no. 3 (1990): 254.

97. Ibid., 253-73; Mathew Kuefler, "The Merry Widows of Late Roman Antiquity: The Evidence of the Theodosian Code," Gender \& History 27, no.1 (April 2015): 28-52.

98. Jerome, Epist. 22.16.

99. Kuefler, "Merry Widows," 42. Kuefler writes, "A childless widow who belonged to the wealthy upper classes, then, had fairly untrammeled economic resources and the freedom to use them as she saw fit." 


\section{Krista Dalton}

unattachment to this world while drawing from a wide network of donors. Megan Hale Williams has argued that the austerity of ascetic life was necessarily shattered by the infrastructures of scholarly expertise, which required libraries, workplaces, tools of the trade, and the means of textual production and dissemination. Williams writes, "Scholarship thereby violates the monastic norm of poverty." 100 Jerome, like others in his position, deployed tactics of negotiation to deflect from the suspicion that donations and elite patronage might alter his monastic virtue.

Jerome's relationship with Paula, however, appears to have sparked accusations of sexual impropriety. Social networks were a subject of much scrutiny, especially if one wanted to denigrate a rival. Jerome, for example, criticized Rufinus for becoming bene nummatus, or "well-loaded," from the support of his patron, Melania. ${ }^{101}$ He decried Rufinus as lacking the sweat of a true scholar, despite Jerome's own reliance on donor networks. On a more severe scale, if a scholar failed to convincingly clarify their wealthy networks, their relationships could compound accusations of heresy. Notably, Priscilian, the fourth-century bishop of Avila, who was executed for his association with both Manichaeism and sorcery, was said to be "a very vain man" who consorted with "many persons of noble rank." Women "flocked to him in crowds" to hear his expertise in the magical arts. ${ }^{102}$ His networks are called to account for his promulgation of heresy.

In a letter to Asella, Jerome decries these rumors concerning Paula, denying both the affair and his receipt of donations. He writes,

I was surrounded by a throng of virgins: to some of them I often discoursed on the Scriptures to the best of my ability: study brought about familiarity, familiarity friendship, friendship confidence. Let them say if they have ever noticed in my conduct anything unbefitting a Christian. Have I taken anyone's money? Have I not disdained all endowment great or small? Has the chink of anyone's coin ever been heard in my hand? Has my conversation ever been ambiguous or my eye wanton?

multa me virginum crebro turba circumdedit; divinos libros, ut potui, nonnullis saepe disserui; lectio adsiduitatem, adsiduitas familiaritatem, familiaritas fiduciam fecerat. Dieant, quid umquam in me aliter senserint, quam Christianum decebat? Pecuniam cuius accepi? Munera vel parva vel magna non sprevi? In manu mea aes alicuius insonuit? Obliquus sermo, oculus petulans fuit? ${ }^{103}$

100. Megan Hale Williams, The Monk and the Book: Jerome and the Making of Christian Scholarship (Chicago: University of Chicago Press, 2008), 4.

101. Jerome, Epist. 125.18.2; 56:137. Peter Brown, in his discussion of women and patronage, describes the charged clashes between Jerome and Rufinus over their connections to wealthy patrons. Brown, Through the Eye, 277.

102. Sulpicius Severus, Chronica 2.46.2, ed. G. de Senneville-Grave, Sulpice Sévere: Chroniques, SC 441 (Paris: Le Cerf, 1999), 334-36. See also Virginia Burrus, The Making of a Heretic: Gender, Authority, and the Priscillianist Controversy (Berkeley: University of California Press, 1995) and Henry Chadwick, Priscillian of Avila: The Occult and the Charismatic in the Early Church (Oxford: Oxford University Press, 1976).

103. Jerome, Epist. 45. 
The letter provides a glimpse at Jerome's perception of his donor networks. Their relationships are framed in the language of his monastic askesis, where his role as expert guide cultivated meaningful and chaste friendships. Jerome's monastic discipline was understood to differ from the normal sources of status for Roman elites. He specialized in exegetical discipline, a method of study available solely to the initiated few and devoid of the trappings of worldly attachment. By framing his relationship with his ascetic followers through his expertise, he is disabusing any suggestion of impropriety.

He follows this framing by rejecting the receipt of money or benefaction. Now we and Jerome both know he received funds from Paula and other Christian ascetic matrons. However, his denial of receiving money, coin, and muneral endowment is a denial of bribes. Bribes were often framed with gifting language in this period. Cyril of Alexandria (378-444 CE), for example, lists a series of bribes given to generate favors in Constantinople, framed as "customary suppliant gifts" eulogiae consuetudinariae supplices. ${ }^{104}$ Jerome deflects the perceived power dynamics of his patronage relationship with ascetic matrons, insisting their gifts have nothing to do with bribery - he is claiming to give them no favors nor special treatment.

Only after decrying the perception of bribery does Jerome address the matter of sexual affairs. Strikingly, the rumors regarding Paula echo the rabbinic association of women's Torah learning with wanton sexuality. Perhaps we could say that this cultural association is informed by a broader fear of amorous relationships forming in the heat of text study. For both Jerome and the rabbis, study was not merely an instrument of expertise, it was the singular act of forming a religious self. Sex proved a distraction from study. While rabbis did not endorse wholesale celibacy, there was acknowledgement that study would necessarily take rabbis away from their wives. ${ }^{105}$ For women donors in particular, where the understood reciprocity for their gifts was attention from their client-scholar, a particular threat emerged: by virtue of their gender and that gender's sexual potential, they could both distract from disciplined study and generate rumors of impropriety.

Within this landscape of donor networks cultivating scholastic culture, the matrona passage now appears as part of a broader pattern of relationships. Scholastic elites strove to balance their autonomy by masking their reliance on donors. Social networks were routinely scrutinized, which made scholars hyperaware of those with whom they forged friendships. Just as Jerome navigated negative perceptions of his relationship with his donor Paula, so, too, Rabbi Eliezer had to manage the influence of his donor, the matrona. Women were very much part of the late antique donor culture, seeing scholastic donations as a means for

104. Cyril, Epist. 96. See Jon McEnerney's note on this phrase in his translation, Cyril and John I. McEnerney, Letters 51-110 (Saint Cyril of Alexandria) (Washington DC: Catholic University of America Press, 2007), 152.

105. M. Ketubbot 5:6 and B. Ketubbot 62b. On the matter of rabbinic celibacy see Eliezer Diamond, Holy Men and Hunger Artists (Oxford: Oxford University Press, 2004) and Michael L. Satlow, "'And on the Earth You Shall Sleep': 'Talmud Torah' and Rabbinic Asceticism," The Journal of Religion 83, no. 2 (2003): 204-25. 


\section{Krista Dalton}

cultivating religious piety. Jerome, as Peter Brown details, "moved in circles that expected women to be as intellectually engaged as men," and belonged to "a generation of great women readers." 106 The matrona sought what many other women like her sought — to participate in the religious enterprise of study.

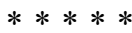

Recent scholarship has taken seriously the broad exchange of gifts described and depicted in rabbinic literature. They build on the legacy of anthropologist Marcel Mauss, who contended that gifts are never free. ${ }^{107}$ Gifts activate an entire social system comprising "religious, legal, moral, and economic" expectations, which inherently place constraints on it. These constraints are particularized for the rabbis, who were both Roman subjects but also inheritors of a biblical system of ideals. ${ }^{108}$ Seth Schwartz has traced the systems of Roman patronage and benefaction in rabbinic texts and identified rabbinic attempts to balance reciprocity with a religious commitment of seeing gifts as mitzvot. ${ }^{109}$ This ideological balancing act further manifested in actual practice. Bernadette Brooten and Susan Sorek have demonstrated how Jewish habits of synagogue donation took distinctly Jewish forms that worked to thwart associations with benefaction. ${ }^{110}$ In a related light, Alyssa Gray, Gregg Gardner, and Yael Wilfand have focused on Jewish charity and its relationship to imperial systems of giving. ${ }^{111}$ Alyssa Gray, in particular, has highlighted the role redemptive almsgiving played in the Palestinian context, which resonated with donors' expectations of reward for their gifts. ${ }^{112}$

This article participates in the renewed focus on giving by examining the function of tithes, as well as broader scholastic donations, in rabbinic literature. The language of tithing is not unique to the rabbis - it has an afterlife in episcopal settings, when Christian bishops used the language of tithing in order to consolidate Christian giving. The rabbis, though, do not simply borrow the metaphor of the Temple. As the rabbis cultivated donor networks, they did so as exegetes. They used the biblical text as the framework for the meaning they created. They drew connections both hyperlinguistically and conceptually to imagine a place for themselves in the lineages of the biblical past. The rabbis inherited a biblical tithing

106. Brown, Through the Eye of a Needle, 274.

107. Mauss, The Gift.

108. Lapin, Rabbis as Romans.

109. Schwartz, Were the Jews, 168.

110. Bernadette J. Brooten, Women Leaders in the Ancient Synagogue: Inscriptional Evidence and Background Issues (Chico: Scholars Press, 1982) and Susan Sorek, Remembered for Good: A Jewish Benefaction System in Ancient Palestine (Sheffield: Sheffield Phoenix Press, 2010).

111. Yael Wilfand, Poverty, Charity and the Image of the Poor in Rabbinic Texts from the Land of Israel (Sheffield: Sheffield Phoenix Press, 2014); Gregg Gardner, The Origins of Organized Charity in Rabbinic Judaism (New York: Cambridge University Press, 2015); Alyssa M. Gray, Charity in Rabbinic Judaism: Atonement, Rewards, and Righteousness (New York: Routledge, 2019).

112. Alyssa M. Gray, "Redemptive Almsgiving and the Rabbis of Late Antiquity," Jewish Studies Quarterly 18, no. 2 (2011): 144-84. 
imperative that cultivated Jewish piety around the organization of agricultural goods. They are the experts of Torah and their expertise is an embodied connection to the memory of the Second Temple past.

In order to situate the matrona's tithe amid a broader pattern of giving, she must first be recognized as a donor. The attitude towards women evinced in the story has attracted more attention than the donor exchange. The matrona and Rabbi Eliezer story appears in a talmudic tractate preoccupied with using the sotah ritual as a site for managing the social capacity of women writ large, as well as their relationship to Torah study. Here I have called our attention to the various points of control exerted by Rabbi Eliezer - he does not simply resign women to weaving rather than Torah study, he resists the power of a particular woman donor to insert herself into his rabbinic space.

Furthermore, the naming of her contribution as a tithe obscures recognition of the tithe functioning within donor networks. I have examined the levels of apprehension informing narrative details in the composition of the textual story. The matrona assumes that her tithe entitles her to R. Eliezer's time and teaching. Rabbi Eliezer's harsh dismissal shifts the power from her gift to his expert authority demonstrated through rabbinic proof texts. Recognizing the matrona as a donor illuminates the function of her tithe. Through the transfer of the gift, Rabbi Eliezer enters into a debt relationship with a donor to whom he owes his attention. When he resists, it is on the grounds that her gender disqualifies her from study, strategically deflecting from the power of a donor's expectations. By parsing the logics of the tithe gift preserved in the matrona story, this rabbinic text attests to the anxieties inflecting potential relationships between donors and rabbis.

Expertise and donations went hand in hand in the late ancient world. Donor networks legitimized the work of scholars and produced tangible objects while generating intangible returns. The matrona and her tithe offer us a case study for analyzing the potential and limits of rabbinic donor networks. In this singular example, we can observe the tensions between rabbis and elite women: the overstepping of learned women into the ideal masculine Torah study, the unsavory demands of a donor to her client and a client to his donor, and the frustrated removal of donations after a scholastic expert dismisses a member of the elite. Each of these dynamics illuminates the position of the rabbis within a broader community of donors within an imperial Roman context wrought with financial choice. 